\title{
(IN)VISIBILIDADES E POÉTICAS INDÍGENAS NA ESCOLA: Atravessamentos imagéticos
}

\begin{abstract}
Alik Wunder"
Alice Villela $^{(*)}$

"Então eu canto um canto desencantado para que as palavras do nosso esforçado canto (mba'ea'ã) também tenham o mesmo sentido, a mesma graça, a mesma grandeza, a mesma luz, a mesma força interior das palavras do teu canto esforçado (mba'ea 'ã)'”.
\end{abstract}

Jeovasa Rañe'ie'y (ore ñe'e ruete).

$\mathrm{Na}$ escuta de cantos (e desencantos) dos povos nativos, propõe-se neste artigo pensar a temática indígena na escola via suas expressões estéticas. Como podemos abrir neste mundo, outros mundos possíveis pela arte do encontro na diferença? Como as imagens indígenas poderiam intensificar as micropolíticas inventivas no sentido de fissurar a imagem genérica do "índio brasileiro"? Como produzir fronteiras férteis no encontro entre as artes visuais, a escola e os povos indígenas brasileiros? O artigo envolve-se por três atravessamentos imagéticos que mobilizam pensamentos sobre a criação de outras visibilidades aos povos indígenas nos currículos escolares. Desejamos uma visibilidade que seja menos sobre os indígenas e mais a partir do encontro com suas forças de expressão e de pensamento. O encontro com o vídeo Ymá Nhandehetama, com o Livro das Árvores do povo Ticuna e com produções de uma oficina de experimentações com palavras e imagens foram três movimentos disparados pelo curso "A temática indígena na escola", oferecido a professores(as) da Rede Municipal de Campinas (SP) em 2016. As leituras de Gilles Deleuze e Félix Guattari sobre micropolíticas, de Eduardo Viveiros de Castro sobre perspectivismo ameríndio e de autores como Suely Rolnik, Iara Bonin e Daniel Munduruku convidam-nos a deslocar as imagens construídas sobre os indígenas e a criar a partir de suas poéticas e regimes conceituais.

O curso desenvolveu questões relacionadas aos modos de vida indígena na atualidade, como política e direitos, terra e território, narrativas, arte, literatura, música, ritual, privilegiando o contato

\footnotetext{
${ }^{(*)}$ Alik Wunder. Professora da Faculdade de Educação da Universidade Estadual de Campinas. Departamento de Educação, Conhecimento, Linguagem e Arte. Mestrado, Doutorado e Pós-doutorado em Educação (Faculdade de Educação - Unicamp); docente e pesquisadora do Departamento de Educação, Conhecimento, Linguagem e Arte Linha de Pesquisa Linguagem e Arte em Educação da Unicampa. Lattes: http://lattes.cnpq.br/3086455648577161. Email: alik.wunder@gmail.com.

Alice Villela. Mestra em Artes pelo Instituto de Artes da Unicamp e Doutorado em Antropologia Social - FFLCH/ USP Lattes: http://lattes.cnpq.br/7316679516223615.E-mail: alicevillela@gmail.com.
} 
com artefatos, contos, filmes, poemas, desenhos e grafismos produzidos por pessoas e coletivos indígenas. Como encontrar, como receber e se deixar atravessar por imagens de povos secularmente silenciados nos espaços escolares? Como reconhecer suas expressões estéticas como potências para desequilibrar nossos modos de ver e perceber? Os indígenas nos oferecem outras imagens, outras visualidades, mundos outros. Lançamo-nos ao desafio de pensar em como as produções indígenas podem criar desassossegos em nossas categorias conceituais como sujeito, humanidade, natureza, infância, tempo...

Entrar em contato com as imagens indígenas leva-nos a outros regimes de verdade e, a partir de leituras de Eduardo Viveiros de Castro (2007), pode-se pensar que somos levados a outros mundos, já que o mundo indígena não é o mesmo que aquele construído pelo pensamento ocidental. Apostamos no encontro com as diversas poéticas indígenas compreendendo-as como aberturas a mundos possíveis e legítimos de coexistir com os regimes de verdade construídos pela cultura escolar nas diversas áreas de conhecimento. Desafiamo-nos a encontrar outros regimes conceituais no sentido de uma educação que se deixe contagiar por estas forças e não somente conceda um lugar dentro de seus já conhecidos territórios de saber. Se cada ponto de vista é um mundo e se o mundo que construímos com o pensamento e a estética ocidental é um dentre muitos possíveis, ir ao encontro de sons, imagens, palavras, modos de pensar dos povos indígenas é um dos desafios de uma educação aberta à diferença.

Eduardo Viveiros de Castro, a partir do conceito de perspectivismo ameríndio, nos convida a conceber os pensamentos indígenas como potências de transformação de nossas epistemologias. $\mathrm{O}$ conceito nos lança desafios: "O que acontece quando se leva o pensamento nativo a sério? O que é pensar o pensamento nativo?" (VIVEIROS DE CASTRO, 2007, p.14). Com o perspectivismo ameríndio e a formulação do multinaturalismo, Viveiros de Castro constrói um instigante movimento de pensamento, atravessado por cosmologias amazônicas:

O perspectivismo ameríndio é a concepção indígena segundo a qual o mundo é povoado de outros sujeitos, agentes ou pessoas, além dos seres humanos e veem a realidade diferente dos seres humanos. [...] A proposição presente nos mitos indígenas é: os animais eram humanos e deixaram de sê-lo. Nas mitologias indígenas todo mundo é humano, apenas alguns desses humanos são menos humanos que os outros (p. 32 e 33).

Nesta metamorfose entre forma humana e não-humana dos regimes conceituais indígenas, há um modo radicalmente outro de compreender o que seja humanidade. Neste modo de pensar os animais são ex-humanos, diferentemente de nossa cultura ocidental que concebe o humano como ex-animal. "Tudo isso senta um pressuposto fundamental de que o fundo comum da humanidade e 
da animalidade não é, como para nós, a animalidade, mas a humanidade" (VIVEIROS DE CASTRO, 2007, p. 76).

O perspectivismo ameríndio produz uma força filosófica que desorganiza o dualismo do pensamento ocidental, a relação entre "natureza" e "cultura" se faz radicalmente distinta daquela que a modernidade criou. No pensamento ocidental há oposição e cisão entre "cultura" e "natureza", uma forma binária de demarcar o mundo. Colocar em desequilíbrio conceitos que nos pareciam "naturais" faz pensar nas malhas que criam os opostos como verdades absolutas. Deleuze e Guattari descrevem um instigante modo de resistir a estas linhas de oposição binárias no texto "Micropolítica e Segmentaridade", do livro Mil Platôs: capitalismo e esquizofrenia - Volume 3. Os autores afirmam que tudo é político e delineiam pensamentos sobre as micropolíticas e macropolíticas: sobre as linhas flexíveis e moleculares da primeira e as linhas duras e molares da segunda, que se fazem em configurações diferentes, no entanto não inseparáveis. As linhas duras e binárias da macropolítica são molares e se efetuam com mais força nas sociedades modernas, aquelas que tem em comum um Estado unificado. As linhas molares definem opostos como: verdadeiro-falso, cultura-natureza, homem-mulher, sujeito-objeto, selvagem-civilizado, passadofuturo. Forças molares que produzem linhas que desejam unificar o poder criando a partição do mundo em dualidades excludentes e desiguais. "Do ponto de vista da micropolítica, uma sociedade se define por suas linhas de fuga, que são moleculares. Sempre vaza ou foge alguma coisa que escapa às organizações binárias” (DELEUZE; GUATTARI, 1996, p. 94). As linhas moleculares potencializam a multiplicidade e se fazem mais intensas nas micropolíticas. Para os autores, as sociedades sem Estado, como as indígenas, possibilitam pensar conceitualmente nas linhas moleculares, nas variações flexíveis menos subordinadas à figura do poder unificado. Pelas segmentaridades flexíveis das sociedades sem Estado, as variações, as mutações, as ambiguidades são potencializadas. Abre-se a possibilidade de pensar pela multiplicidade e ambivalência: gente e bicho e planta e homem e mulher... Os autores não afirmam que a sociedades modernas são em si molares e que todas as sociedades indígenas são, portanto moleculares. Deleuze e Guattari fazem do encontro com outros modos de organização social um disparador de pensamentos sobre as linhas duras de aglutinação do controle e do poder e as linhas de fuga que criam as variações e escapes. Para eles:

Cada centro de poder é igualmente molecular, exercendo-se sobre um tecido micrológico onde ele só existe enquanto difuso, disperso, desacelerado, miniaturizado, incessantemente deslocado, agindo por segmentações finas, operando no detalhe e no detalhe do detalhe. Há sempre focos de instabilidade onde há escapadas e fugas, e onde se produzem inversões (DELEUZE; GUATTARI, 1996, p.104). 
Podemos pensar que o perspectivismo ameríndio produz uma força filosófica molecular nas linhas duras do pensamento dualista moderno. Os diferentes povos indígenas nos oferecem, não apenas outras formas de relação com aquilo que chamamos de natureza, eles nos oferecem múltiplas naturezas. Oferecem-nos olhares que não se centram em um fundo comum, abrem fissuras na própria ideia de que há algo pré-existente anterior aos olhos. Oferecem-nos um modo outro de pensar o próprio olhar, atravessado por perspectivas (consideradas por nós) não-humanas. Perguntamo-nos: como estes mundos poderiam intensificar as micropolíticas inventivas do pensamento? Como poderiam potencializar linhas moleculares em movimentos que abram frestas nas malhas duras da visualidade moderna sobre os povos indígenas? Como produzir encontros com estes outros povos de modo que as compreensões do que é ser homem, mulher, humano, natural sejam atravessadas por forças desestabilizadoras? É a partir destes desafios conceituais que lançamos nosso pensamento a diferentes artistas que criam obras literárias, musicais, instalações, performances, desenhos, filmes a partir da aproximação com mundos indígenas. E com estas imagens, palavras e sons propomos encontros de criação com professores(as), potencializando as micropolíticas inventivas na pesquisa, na arte e nos cotidianos escolares.

\section{ATRAVESSAMENTO 1: VÍDEO YMÁ NHENDEHETAMA, ${ }^{1}$ ERAMOS MUITOS ${ }^{2}$}

"Nós sempre fomos invisíveis. Os povos indígenas sempre foram invisíveis para o mundo. Aquele ser humano que passa fome, passa sede, que é massacrado, perseguido, morto lá na floresta, nas estradas, nas aldeias, este não existe. Para o mundo de fora existe aquele índio exótico que usa cocar, que dança, que canta, coisas para turista ver. Aquele que está lá na aldeia sofre da doença de ser invisível, de desaparecer. Ele quase não existe para o mundo do direito, principalmente para o mundo do direito, como ser humano. Como ser humano, ele desaparece. Se afoga no mar das palavras da burocracia, das teorias acadêmicas. Ele é afogado no meio das palavras quando a academia, os estudiosos entendem mais de índio que o próprio índio. Ele é invisibilizado pela própria academia. Ele perde a voz, perde o foco, perde a imagem. Ele volta novamente quando tem o conflito, quando a mídia procura a notícia para vender o jornal, mostra o índio morto, o índio bêbado, preguiçoso, como se vê nos livros. O índio que quer muita terra, o índio que tem muita terra, este aparece, e aquele índio como ser humano, aquele que tem direitos, este desaparece, este sempre desapareceu... vai sumindo aos poucos. É como um grito no silêncio da noite, ninguém sabe de onde veio, ninguém sabe onde encontrar".

Almires Martins (no vídeo Ymá Nhendehetama)

\footnotetext{
${ }^{1}$ Vídeo selecionado e exibido na $31^{\text {a }}$ Bienal de Arte de São Paulo em 2015, produzido por Armando Queiroz, Almires Martins e Marcelo Rodrigues.

${ }^{2}$ A reflexão apresentada nesta seção foi publicada no artigo "Encontros com poéticas indígenas, férteis fronteiras entre a educação e as artes”, na Revista de Estudos em Educação Questio (WUNDER, Alik. Uniso, Sorocaba, v. 19, n. 3, dez. 2017).
} 

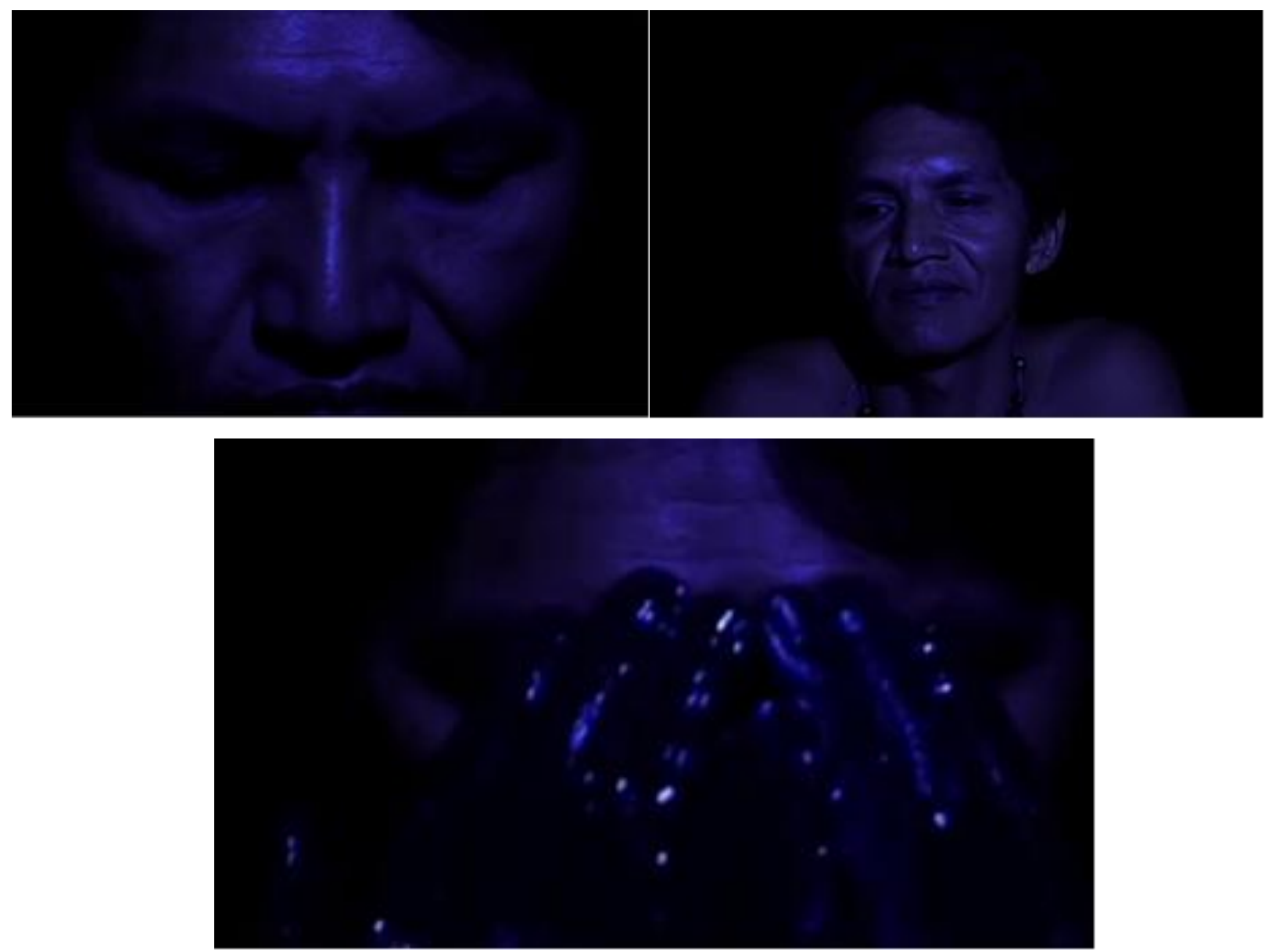

Imagens 1, 2 e 3: Frames do vídeo Ymá Nhendehetama (2015).

Uma luz azul banha um corpo, rosto e peito nu. Não há contexto ou qualquer outra referência - legenda, voz em off, texto de abertura - que nos possibilite contextualização de espaço ou tempo. Surge no filme um corpo em performance, um olhar desviante, que se desafia a rasgar um silêncio histórico: o testemunho impossível do desaparecimento de muitos. O rosto imóvel contrasta com a fala precisa, densa e articulada entremeada por silêncios que adensam o tempo. Há uma voz que se faz híbrida, entre a fragilidade e a força. Uma voz que nos rasga com afiada precisão. As palavras, também híbridas, apresentam uma aguda crítica ao campo do direito, à ciência, ao jornalismo e guardam o silêncio e a pausa de muitas línguas. Almires Martins, guarani e terena, é quem fala. Primeiro doutor indígena em antropologia da Universidade Federal do Pará, graduado em direito e mestre em Direitos Humanos. Uma palavra singular e dissidente que abre um outro espaço político e estético, "uma fenda nos discursos do poder" como nas palavras de Eugenia Vilella (2016, p.114). O vídeo produz "desde dentro de uma falha, onde os discursos que definem o território político se separam das palavras singulares, isto é, das palavras de sofrimento, das palavras ditas em sofrimento" (p.115). Esta voz guarani não se deixa inserir no lugar de objeto da ciência, objeto de conhecimento, representado por uma diversidade de discursos que se debruçam sobre ele. Traz, na sua palavra singular e dissidente, a voz de muitos. Voz que rasga com 
desconforto a malha da invisibilidade que nos envolve. E nesta fronteira fértil entre a antropologia, a arte e as culturas indígenas, nesta fala de um guarani acadêmico, abrem outras visualizações. Um vídeo que instiga pensar na importância e urgência de outras lógicas, de outras linguagens, de outras existências habitarem o pensamento acadêmico e escolar.

Temos circulado com este vídeo entre professores(as) desafiando-nos a pensar em como produzimos a invisibilidade indígena nos discursos e imagens das universidades e da escola moderna. As conversas envolvem as invisibilidades que se fazem no apagamento da presença indígena na história das cidades, das famílias, quando não nos damos conta da permeabilidade indígena em nossa língua, quando desconhecermos a ampla diversidade de povos que vivem hoje no Brasil, povos que mal sabemos nomear. É especialmente sobre a invisibilidade que se produziu (e produz) nas culturas escolares que movimentamos pensamentos.

A figura do índio é presença marcante na escola moderna, especialmente para delinear a constituição da nação e do povo brasileiro. Iara Bonin (2012) diz que a abordagem dos indígenas por um viés celebratório, acaba por ressaltar o exotismo de certas condutas ou a riqueza da diversidade e daquilo que se poderia destacar como contribuição indígena à constituição de uma suposta cultura nacional unificada. É pela via da formação do Estado, pela linha molar da identidade nacional, que a imagem do indígena se constrói, desta ficção se constrói a imagem do "índio brasileiro". Uma linha unificadora que apaga as relações desiguais de saber e poder e faz da multiplicidade de povos uma figura genérica e vazia.

Em um outro texto, Iara Bonin (2010) coloca-nos os desafios e campos minados dos discursos e práticas que apostam na diversidade cultural na educação. Para a autora, muitas vezes a retórica da diversidade vem apenas como uma possível concessão ao outro, na lógica do mesmo. As diferenças "não são vistas como produções culturais, como efeitos de relações assimétricas e de disputas dentro daquilo que definimos como normal-anormal, comum-estranho, o mesmo-diferente" (p.75). Muitas práticas e discursos que na intenção de fazer visível o pluralismo cultural e de clamar por uma vivência harmônica entre povos tratam as culturas de modo superficial e externo, exaltando o exótico.

Bonin pontua as diversas invisibilidades produzidas no interior das imagens escolares do indígena. Aquela que se faz no apagamento da violência histórica de um genocídio. Estima-se que em 1.500 viviam de 3 a 5 milhões de pessoas de mais de 1.000 etnias no território que hoje se configura como nação brasileira. Também se apagam os rastros das resistências indígenas no período colonial, sua presença nos quilombos e nas diversas guerras travadas entre etnias e 
colonizadores. Apaga-se a história pré-colonial de diversos povos, suas resistências à guerra de ocupação, e reafirma-se a subordinação do indígena ao colonizador, nas inúmeras imagens de livros didáticos que reproduzem a clássica cena do descobrimento. Em geral, é esta a primeira imagem do indígena que os livros oferecem: a mansidão indígena diante do desembarque de Cabral. Imagem que se desdobra em repetição, das pinturas da época colonial às ilustrações contemporâneas. Em especial, na data comemorativa 19 de abril, os 300 povos indígenas contemporâneos são invisibilizados por uma figura genérica, o "índio". O índio construído pela escola moderna é uma figura genérica "com traços mínimos, fixos, memoráveis e reconhecíveis: aldeado, que usa cocar, arco e flecha e pintura corporal, nu, primitivo, ingênuo, isolado, em harmonia com a natureza, o “bom selvagem” (BONIN, 2010, p.81). Um estereótipo que se faz como estratégia de reduzir o diferente em semelhante, um modo de acomodar as tensões e conflitos, de fixar o que se chama de outro em uma imagem para melhor controlá-lo e de não adentrar nos traços da diferença que nos inquieta, transforma e mobiliza. Para o escritor Daniel Munduruku, o "índio" é um apelido dado pelo colonizador para diminuí-lo e expressa a negação das ancestralidades indígenas: "a escola só nos ensinou a desqualificar os povos ancestrais. Ela não nos ensinou a chamá-los pelo nome ou a compreender suas diferentes formas de humanidade" (MUNDURUKU, 2017, p.22).

E seguem-se muitos outros apagamentos entremeados a estes: a cristalização da identidade indígena sem compreensão de suas dinâmicas de transformação, a visão evolucionista que coloca o indígena no passado e sua cultura como primitiva em relação às culturas europeias, e a relação direta entre as culturas indígenas com o que se chama "folclore brasileiro". Nesta última abordagem, as narrativas indígenas e seus complexos saberes chegam na escola como lendas e crendices e não como outros regimes de verdade. Estes modos de dar (in)visibilidade apagam múltiplas imagens que se fazem nos movimentos indígenas de luta por direitos, em especial pela demarcação de seus territórios; nos seus complexos processos de reinvenção identitária; na diversidade étnica e linguística; nas cosmovisões; nas experiências com o sagrado; nas expressões estéticas e poéticas indígenas no cinema, na literatura, na música... A presença indígena na literatura e no cinema não é recente, nas últimas duas décadas cresceram as produções de indígenas que têm por efeito problematizar as imagens feitas até então a seu respeito, dando visibilidade a uma multiplicidade do olhar que dialoga diretamente com a diversidade dos povos. E como deixar-se atravessar por estas diferenças que nos impõe outras lógicas? Sueli Rolnik diz que "temos o desafio de reinventar nossas capacidades de percepção de forças vivas, de inventar novas formas de presença, novas texturas sensíveis que apostem na diferença” (2017, s.p.). Construir outras 
condições de percepção destas forças vivas na educação e na pesquisa é afirmar as micropolíticas que fazem buracos e criam linhas de fuga nas malhas molares do pensamento e da estética moderna.

\section{ATRAVESSAMENTO 2: O LIVRO DAS ÁRVORES DO POVO TICUNA}

"Eware é a nossa terra sagrada. É o começo do mundo onde foi criado o povo Ticuna. Nesse lugar corre o igarapé que também se chama Eware onde nosso deus Yo’i nos pescou. Eware, tuas árvores e tuas águas são nossa herança. Ewane é protegido por animais e gente encantada. De cada lado do igarapé ainda estão a casa de Yo’i e de Ipi, assim como antigamente. Também estão o caniço que os irmãos usaram para pescar os animais e as pessoas".

O Livro das Árvores Ticuna.

O Livro das Árvores Ticuna foi escrito e ilustrado por professores(as) Ticuna e publicado pela Organização Geral dos Professores Bilíngues Ticuna. O povo Ticuna tem aldeias distribuídas no Brasil, Peru e Colômbia e vive em mais de 20 áreas indígenas, localizadas especialmente no alto Solimões, estado do Amazonas. ${ }^{3}$ O livro foi criado para mais de 7.000 alunos das 90 escolas Ticuna localizadas no município de Benjamin Constant (AM). Levados pela necessidade da preservação das florestas de suas áreas demarcadas, os(as) professores(as) criaram um livro sobre seus conhecimentos das árvores, com desenhos individuais e textos coletivos. Embora destinado às crianças indígenas, o livro é um rico material para adentrar nos modos de percepção e conhecimentos da floresta amazônica na perspectiva de seus habitantes. Por meio de desenhos e narrativas, transcritas para o português, os Ticuna abrem para nós uma gama de possibilidades perceptivas e de modos de expressão de seu mundo.

floresta é a coberta da terra. Aqui nós nascemos. Aqui viveremos para sempre. Na terra do povo Ticuna tem lagos, igarapés, rios, igapós, paranás. Tem árvores altas e baixas, grossas e finas. Com âmago e sem âmago. Tem árvores verde-escuro e verde-claro (O Livro das Árvores Ticuna, 1997, p.8, 9 e 10).

Deste modo se inicia a narrativa do Livro das Árvores Ticuna, apresentando ao leitor a diversidade das árvores de seu território. Os Ticuna não desenham árvores genéricas ou uma ideia genérica de árvore, dirigem-se a cada árvore que conhecem e diferem umas das outras em cada um dos seus detalhes. As imagens ticuna levam a pensar no modo que a escola não-indígena lança seu olhar sobre as árvores. As variações das imagens no livro põem-nos a pensar sobre nossa sociedade que, em geral, não nos ensina a perceber a multiplicidade que é uma árvore e uma floresta. A árvore genérica escolar não é um simples estereótipo imagético, é a expressão de um modo de olhar que

3 Dados do site Enciclopédia dos Povos Indígenas do Brasil, organizada pelo Instituto Socioambiental pib.socioambiental.com.br (acessado em outubro de 2017). 
limita nossas percepções e relações com a floresta. As relações que se estabelecem com as árvores são atravessadas especialmente pela ideia de floresta como objeto de estudo e recurso natural. Os Ticuna observam e experimentam o mundo sensível que os cerca e os desenhos das árvores revelam seu extenso conhecimento da floresta. "Este livro ajudará a lembrar que cada árvore tem sua importância. Que as árvores formam a floresta. E a floresta é a maior riqueza que deixaremos para nossos filhos" (O Livro das Árvores, 1997, p. 92).

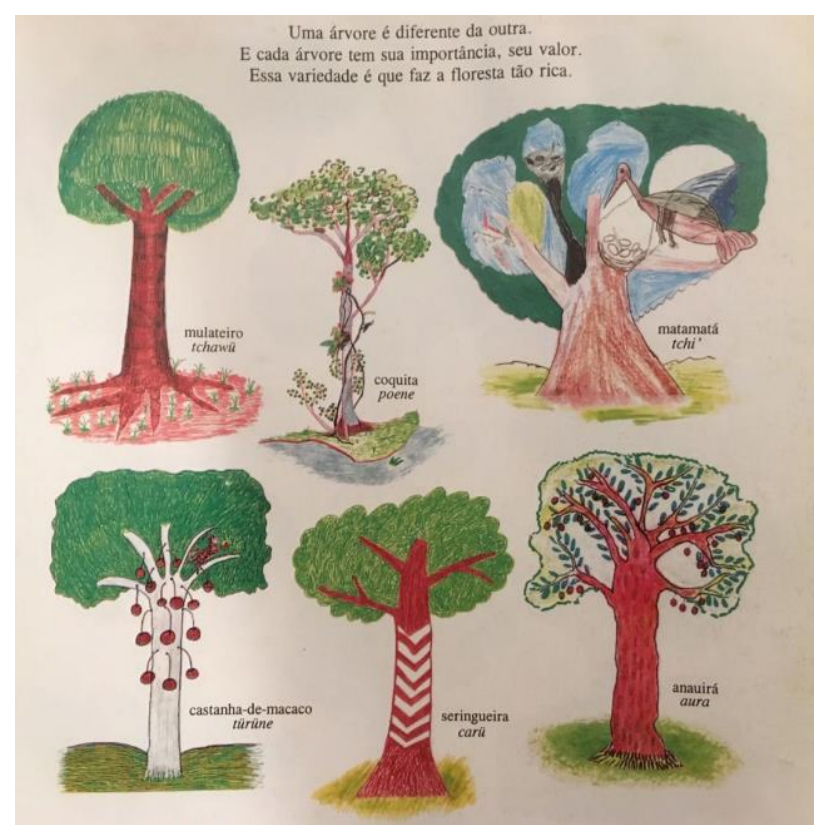

Imagem 4. Fonte: O Livro das Árvores, 1997, p. 11.

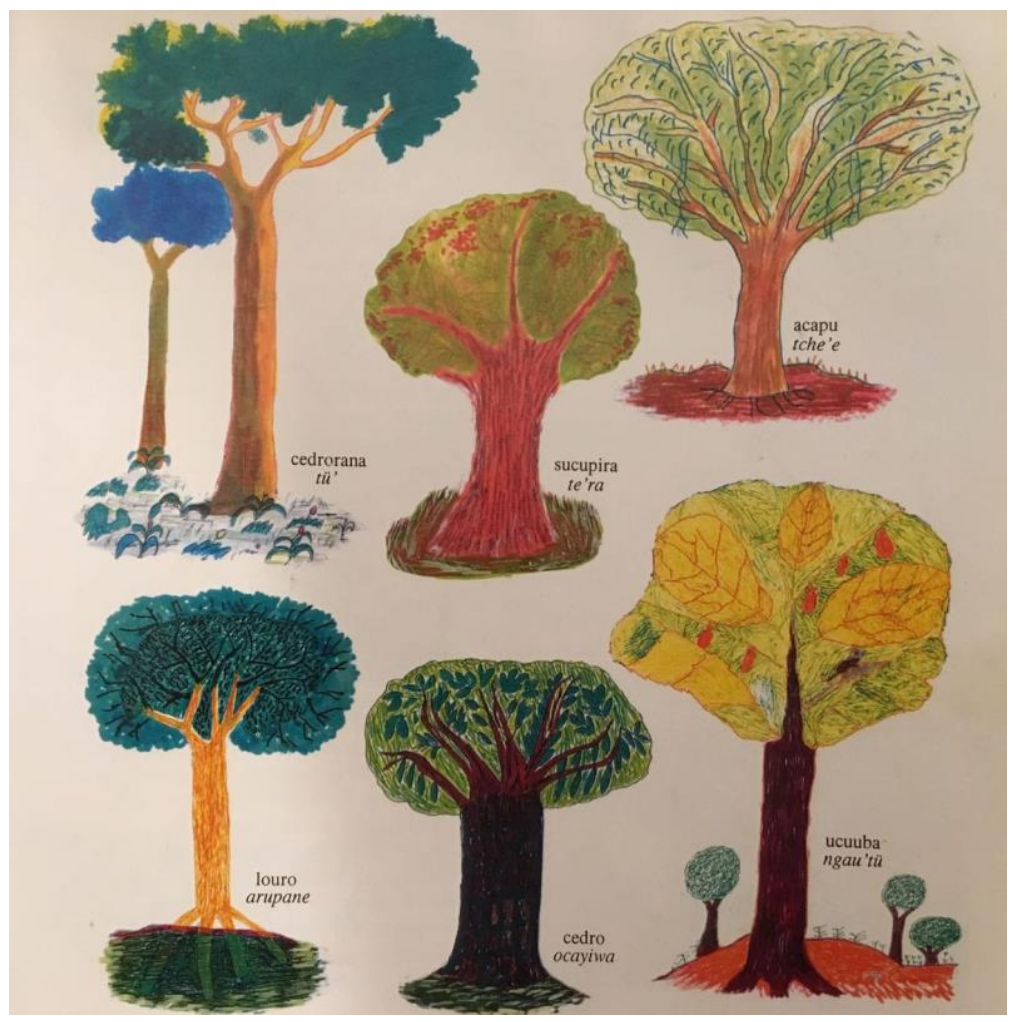

Imagem 5. Fonte: O Livro das Árvores, 1997, p. 12. 
As próximas imagens trazem a palmeira buriti a partir da perspectiva e da criação de vários professores(as). Os Ticuna não percebem o mundo e se expressam da mesma maneira, há uma multiplicidade de expressões individuais no âmbito da coletividade indígena. Singularidades inventivas de um povo e de seus professores(as) que oferecem ao mundo suas criações.

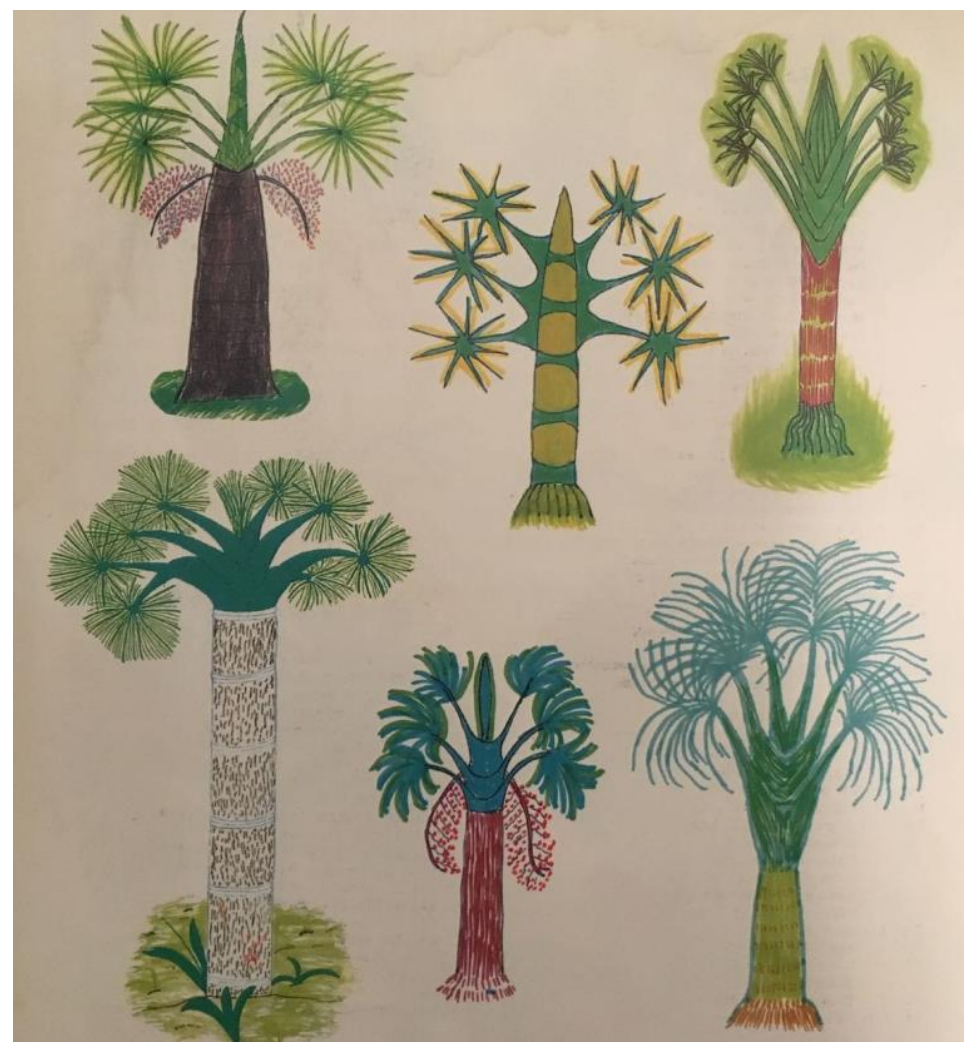

Imagem 6. Fonte: O Livro das Árvores, 1997, p. 94.

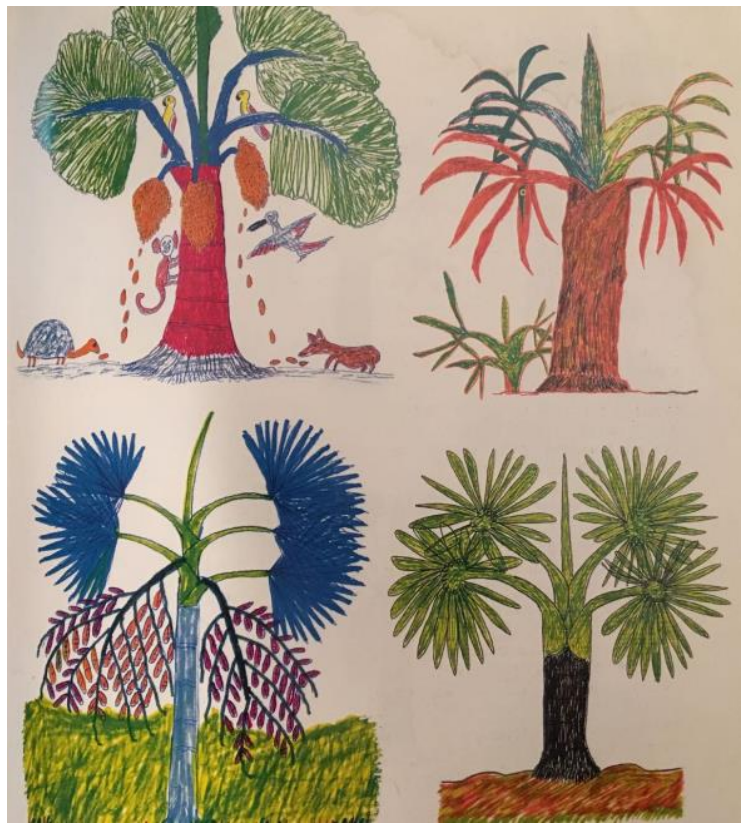

Imagem 7. Fonte: O Livro das Árvores, 1997, p. 93. 
O livro apresenta uma rica e intensa teia entre os Ticuna e as espécies que formam a floresta. Falar das árvores permite aos professores(as) Ticuna tratar da conservação de seu território e do valor da floresta para a vida ticuna, das fontes de alimento, da matéria-prima para confecção de casas, objetos e remédios, dos animais, dos ciclos que mudam ao longo do ano. As suas relações com a floresta se estabelecem fortemente pela presença das árvores em suas cosmologias de origem do mundo: uma grande samaumeira impedia que a luz entrasse no mundo; ao cair, a luz apareceu e de seu tronco formou-se o rio Solimões, de seus galhos surgiram os outros rios e igarapés, dos frutos das árvores surgiram os peixes nos igarapés, dos peixes pescados surgiram os bichos e o povo Ticuna. O livro traz uma "memória das árvores" para usar um termo empregado pela organizadora, Jussara Gruber, que permite aos Ticuna recordar a importância de cada uma delas na sua vida.

Os Ticuna nos trazem imagens de uma natureza que passa longe de ser apenas fonte de recursos; a floresta é povoada de intencionalidades, sujeitos, seres, espíritos e os donos, "[...] seres que cuidam há milhares de anos de tudo o que existe na natureza, assim como nós cuidamos de nossos filhos e de nossas roças" (O Livro das Árvores, 1997, p.28), para usar a própria definição dos(as) professores(as). Com os animais e com demais seres os Ticuna travam relações sociais, ou seja, relações entre sujeitos, concepção que dialoga com a teoria do perspectivismo ameríndio desenvolvida por Viveiros de Castro. Na narrativa "O jenipapo e a origem das pessoas" (p.18), vemos o fundo transformacional entre os seres: a borra de jenipapo transforma-se em peixes, os peixes pescados quando caem na terra viram outros animais (queixada, anta, veado, caititu), peixes pescados com isca de macaxeira viram gente; da gente pescada por Yo'i, espécie de herói mítico, descendem os Ticuna.

No curso desafiamos os professores(as) a pensar com imagens e textos do O Livro das Árvores desestabilizando nossas ideias fixas e sedimentadas do conceito de natureza. A passagem sobre "Ngewane, a árvore dos peixes" narra em detalhes como a árvore encantada que existe desde o princípio do mundo deu origem aos peixes. 


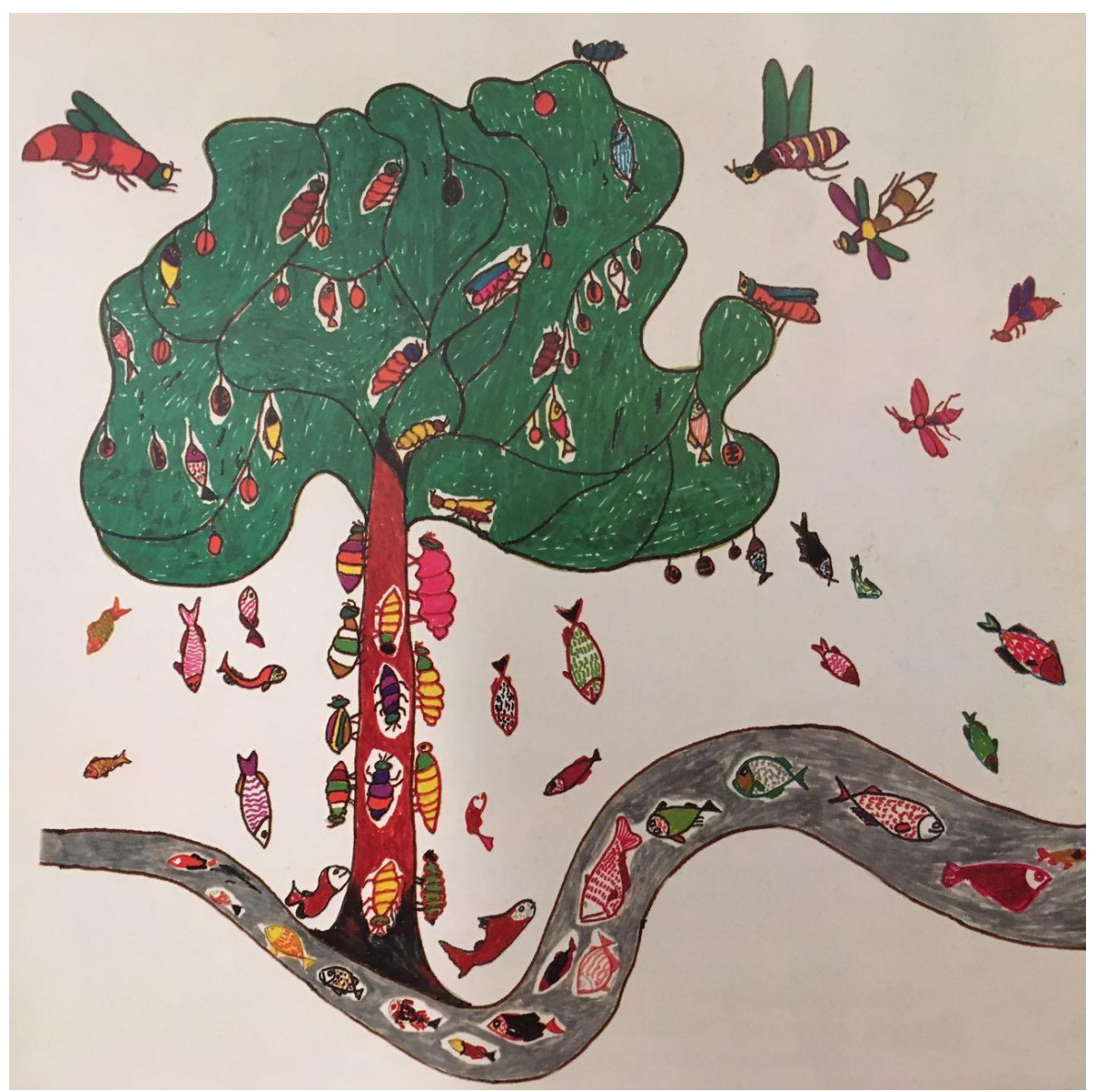

Imagem 8. Fonte: Livro das Árvores, 1997, p. 39.

[...] Quando chega o tempo, depois das chuvas e ventos, as folhas desta árvore caem e no seu tronco começam a aparecer pequenos ovos, parecidos com ovas de rã. Os ovos se transformam em lagartas, muitas lagartas, que sobem pelo tronco e andam até os galhos para comer as folhas novas. Aí elas vão crescendo, crescendo, durante uns dois ou três meses. De repente, as nuvens se juntam para chover, e começa a tempestade. Os raios e os trovões fazem as lagartas descerem e entrarem nas raízes da árvore. Suas cascas, como algodão, ficam soltas sobre as sapopemas. A chuva vai aumentando. Quando a água sobe, as lagartas saem transformadas em peixes, em vários tipos de peixes, grandes e pequenos: matrinxã, jaraqui, pacu, curimatã, jeju, pirapitinga, bacu, piabinha, piranha, aracu, tambaqui, samoatá, piau, jundiá, traíra, carauaçu, acari, pirarucu, sardinha, surubim, tucunaré, bodo, branquinha, pescada, poraquê, pirabutã, sarapó, jacundá, mandi, arenga, aruanã. Os peixes, já ovados, se espalham pelas águas e ganham a caminhada para os igarapés, lagos e igapós. Depois, uma parte alcança o rio, subindo em piracema. Esses peixes servem para alimentar as pessoas. (O Livro das Árvores, 1997, p. 36 e 37)

Há no regime de verdade Ticuna um modo outro de explicar os ciclos biológicos em relação aos conhecimentos biológicos da ciência ocidental. Como lidar com esta diferença radical na escola, quando os saberes dos povos indígenas não correspondem aos saberes biológicos construídos pela ciência? Pode-se olhar para esta narrativa como a lenda que expressa a crença do povo Ticuna. Ao 
definir a relação dos Ticuna com seu discurso em termos de crença e suas narrativas como lendas, corremos o risco de entender as suas produções culturais como erro, ilusão ou loucura e perder a oportunidade de entrar em contato com um povo indígena e seus mundos outros, cegos demais que estamos pelas lentes do nosso próprio modo de ver, considerado científico e verdadeiro. Como observa Latour (1996, p.15), "a crença não é um estado mental, mas um efeito da relação entre os povos". Embora, sob a ótica ocidental esta narrativa possa ser classificada como "conto folclórico", lenda ou uma história fantástica, do ponto de vista ticuna trata-se de uma narrativa tradicional que fala sobre a origem dos peixes e que é atual, muito distante da ideia de lenda.

Trazemos aqui uma narrativa de um historiador e contador de histórias da etnia Kariri-Xocó, Nhenety Kariri-Xocó, que nos ajuda a pensar o estatuto de verdade das narrativas para os próprios indígenas versus o modo como estas narrativas soam aos ouvidos dos não-indígenas. Ele conta a resposta que deu a uma pesquisadora que foi à sua aldeia fazer pesquisas sobre os "mitos e lendas" kariri-xocó. Ele diz:

Respondi para a universitária que aqui na tribo não existia mitos e lendas. Ela levou um tremendo susto. Expliquei que entre os índios "mitos e lendas são verdades absolutas”, não é fantasia, nem mentira como contam os livros. Acreditamos na "Mãe d'água" que é guardiã dos rios, dos peixes. Recebemos notícias da natureza através dos cantos dos pássaros, insetos e dos fenômenos atmosféricos, coisas boas ou ruins podem acontecer. As formigas quando saem do formigueiro é sinal que vai chover. Quando o joão-de-barro faz sua casinha de argila com a porta virada para o Norte é porque vamos ter um inverno chuvoso. O índio acredita em sua cultura, porque é uma verdade pura. A partir do momento que não acreditar em sua cultura, religião indígena, estará tudo perdido. (NHENETY KARIRI-XOCÓ, 2016, s.p.).

Como trabalhar com regimes de verdade outros na escola? O que propõe o antropólogo Eduardo Viveiros de Castro no texto Nativo Relativo (2002) para a antropologia, pode iluminar o modo como a educação pode se abrir ao conhecimento indígena. $\mathrm{O}$ autor sugere que se recuse a vantagem epistemológica do discurso antropológico sobre a do nativo e que se entenda a relação de conhecimento como suscitando uma modificação, necessária e recíproca, ou, de outro modo, podemos perguntar: "o que acontece quando se leva o pensamento nativo a sério?" (2002, p. 129). Ao invés de a antropologia explicar, interpretar, analisar e contextualizar esse pensamento, Viveiros de Castro sugere que o procedimento possa ser o de utilizá-lo e verificar os efeitos que ele pode produzir no nosso: "Se há algo que cabe de direito à antropologia, não é certamente a tarefa de explicar o mundo de outrem, mas a de multiplicar nosso mundo" (VIVEIROS DE CASTRO, 2002, p. 132, grifos do autor). 
O encontro com $O$ Livro das Árvores nos propõe pensar sobre o que se ensina e aprende sobre o que chamamos de natureza na escola. Que imagens deste mundo natural a escola oferece ao aluno e como estabelece relações de conhecimento sobre a natureza e sobre as árvores? As imagens ticuna possibilitam pensar sobre o que se cria no atravessamento dos olhares-conceitos de natureza (e humanidade) do povo Ticuna em relação ao modo como se vê e pensa a natureza (e a humanidade) em nossa cultura. Os Ticuna nos convidam a pensar sem conceber um real préexistente, como se a natureza fosse um denominador comum, mas a aceitar a coexistências de naturezas e humanidades várias.

\title{
ATRAVESSAMENTO 3: OFICINA DE CRIAÇÃO FOTOGRÁFICA E POÉTICA, MICROPOLÍTICAS INVENTIVAS
}

\author{
"Então os Seres-Trovões disseram: \\ 'Nós e nossos filhos seremos revolvidos pela Terra \\ e nesse revolver proveremos palavras em pé pelo chão. \\ Sons andantes cantarão vidas, cada qual seu tom ",".
}

Kaka Werá Jecupé.

Como construir outras condições de percepção de maneira que as vozes indígenas ganhem força por suas dissonâncias, por suas variações de vidas e tons? As palavras de Almires Martins em Ymá Nhandehetama e a leitura dos textos de Iara Bonin e Daniel Munduruku nos levaram a procurar as imagens que proliferam em repetição nos livros didáticos, nos cartazes, nos gibis, nas páginas da internet, nas ilustrações de livros infanto-juvenis... Imagens que, em geral, fixam o indígena nas marcas identitárias generalizantes". Também fomos à procura de poéticas visuais indígenas: grafismos de pintura corporal do povo Asuriní, desenhos de árvores e de seres da floresta do povo Ticuna (O Livro das Árvores Ticuna), desenhos e palavras de sonhos de xamãs do povo Yanomami (Mitopoemas Yanomam de Claudia Andujar e Pietro Bardi) e poemas de escritores e escritoras indígenas como Eliane Potiguara, Olívio Jekupé (guarani), Kaká Werá Jecupé (tapuia), entre outros (Revista LEETRA - Ufscar). Em meio a este conjunto de imagens e palavras nos enveredamos por um movimento de experimentação ${ }^{4}$. O experimentar que buscamos realiza-se na composição entre palavra poética e imagens e entre pessoas, espaços, gestos, sons, tensões, experiências de vida... Esse movimento pressupõe atmosferas aptas ao encontro, sensíveis a um

\footnotetext{
${ }^{4}$ As oficinas de experimentação com imagens e palavras têm sido realizadas pelo Núcleo de Leituras da Associação de Leitura do Brasil, ligada aos movimentos do Coletivo Fabulografias (Faculdade de Educação - Unicamp) desde 2010. Nesta oficina do curso "A Temática Indígena na Escola" estiveram presentes os(as) professores(as) da rede Municipal de Campinas: Márcia Soares, Marcello Guriam, Andressa Gonçalves dos Santos de Andrade, Kerstin Cunha, Francisca Almeida, Daniela Marques Fernandes, Aurora Ferreira, Diego Alexandre, Érika Bizari, Elaine Cristina, Simone Assunção, Waneska Oliveira, Suely Oliveira, Viviane Valente, Narcleyre Dias e Fátima Bredariol.
} 
silêncio e ao desejo de produzir pontos singulares e disjunções nos processos de criação coletivos (WUNDER; ROMAGUERA e MARQUES, 2017).

Desafiamo-nos com os(as) professores(as) a criar "cartões postais" por meio de deslocamentos e invenções com os materiais selecionados. Com recortes e colagens criamos conexões improváveis entre as imagens e palavras sobre indígenas que percorrem a cultura escolar e pinturas, desenhos, poemas que os diferentes artistas indígenas nos oferecem. Enveredamo-nos pelas criações com o desejo de produzir micropolíticas imagéticas no gesto antropofágico de devorar clichês. Propomo-nos a pensar na imagem como movimento constante, como um contínuo deslizar sobre outras imagens. Nesta perspectiva, não se deseja colocar sobre os clichês imagens mais verdadeiras e sim movimentá-los, rasurá-los, abrir fendas multiplicando os campos de possíveis com as poéticas indígenas. As oficinas pensam a imagem como um contínuo movimento que se prolifera no encontro e apostam nas micropolíticas inventivas que se desdobram das expressões singulares dos povos. Apostamos também nas micropolíticas inventivas que se dão no gesto de criação dos(as) professores(as) que, debruçados(as) sobre o debate da fixação imagética dos indígenas na escola, produziram cartões em um espaço de criação conjunta em que uma imagem disparava outras. ${ }^{5}$ Entendemos as oficinas como processos de criação coletiva e definimos a autoria das imagens também como coletivas, potencializando a força das imagens e palavras que se desdobram nos encontros.

Neste movimento criativo, as imagens do "índio escolar" secularmente sedimentadas em cantigas e caricaturas são rasuradas por dizeres outros, pela voz de Almires Martins, do povo terena, do povo guarani, de povos muitos que já nem podemos nomear. Um jacaré gigante devora a imagem que povoa os livros didáticos e faz ver toda violência histórica que ela apaga. As imagens sob a perspectiva colonial ganham fendas na composição com vozes outras que denunciam o genocídio do passado e do presente. Composições que fazem ver a violência dos discursos que desejam harmonizar a história da formação de um povo e de uma nação.

A'e va re ndeé, yvy py ma reikóvy, che amba porã re ne ma'endu'a va'erã. Cheé aroñemongeta ramo nd'apytére, nde reko wboovái arã jipói va'erã yvy rupa reko achy re. (Jecupé, 2001, p.86). Palavras guarani. Línguas outras criam uma dissonância na língua portuguesa, nos pedem a escuta de sonoridades e sentidos inapreensíveis. Linhas gráficas ampliam horizontes visuais, traços incompreensíveis que se fazem em cestos, tecelagens, pulseiras, peles... Corpos envoltos por

\footnotetext{
${ }^{5}$ Estas e outras imagens criadas na oficina foram publicadas na Revista ClimaCom Cultura Científica - pesquisa, jornalismo e arte. Disponível em: http://climacom.mudancasclimaticas.net.br/?p=6349.
} 
grafismos que expressam a geometria de um mundo que não conseguimos compreender. Imagens que fazem do corpo vivo e dos objetos obras de arte que habitam o mundo cotidiano em ritual... Que outros conceitos de arte, de vida, de ritual estas imagens podem nos oferecer?

Seres errantes, mutantes e ambíguos vagueiam pelos poemas e borram os limites do humano e do que chamamos de inumano - gente-rio-peixe-flor-colina-névoa -, criam linhas flexíveis entre a humanidade e as coisas da natureza. O mundo todo se torna humano, mas o humano é outra coisa. Os imaginários enriquecem-se e proliferam no encontro com sonoridades, vozes, línguas, traços, seres, conceitos, pensamentos... Uma coexistência de povos faz variar as linhas molares unificadoras e multiplica os horizontes daquilo que chamamos de humanidade. Viveiros de Castro diz que estes "povos em estado de variação contínua contêm uma imensa reserva inconsciente de diferença capaz de gerar muitos outros futuros" (VIVEIROS DE CASTRO, 2015, p.10). Quando as forças molares da macropolítica querem nos determinar a existência de um futuro único, proliferar poéticas indígenas - e outras poéticas da diferença - parece ser um modo de fertilizar imaginários de outros futuros possíveis, de multiplicar passados coexistentes e fertilizar as micropolíticas do presente.

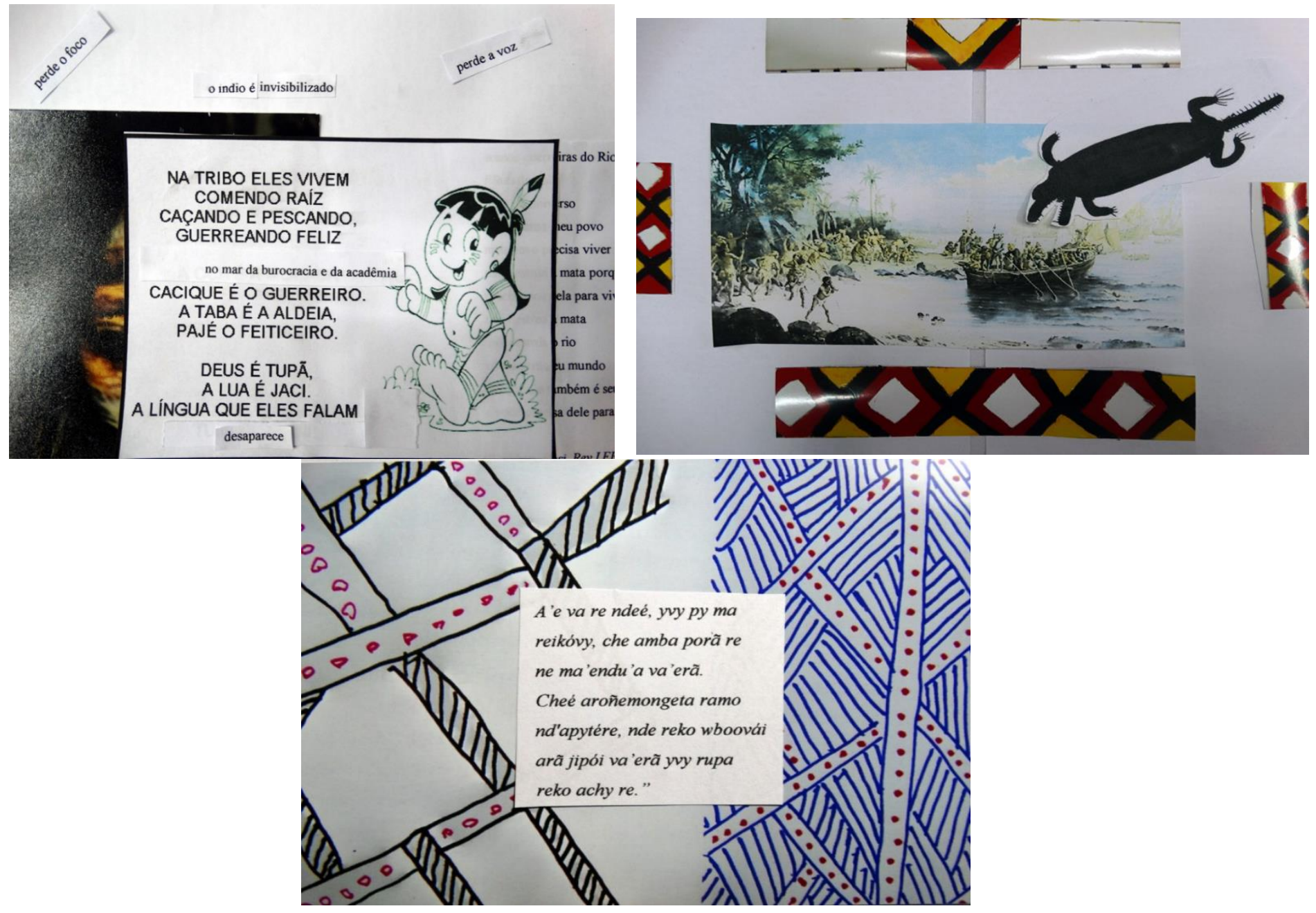

Imagem 9, 10 e 11. Fonte: Oficina de criação com palavras e imagens. 

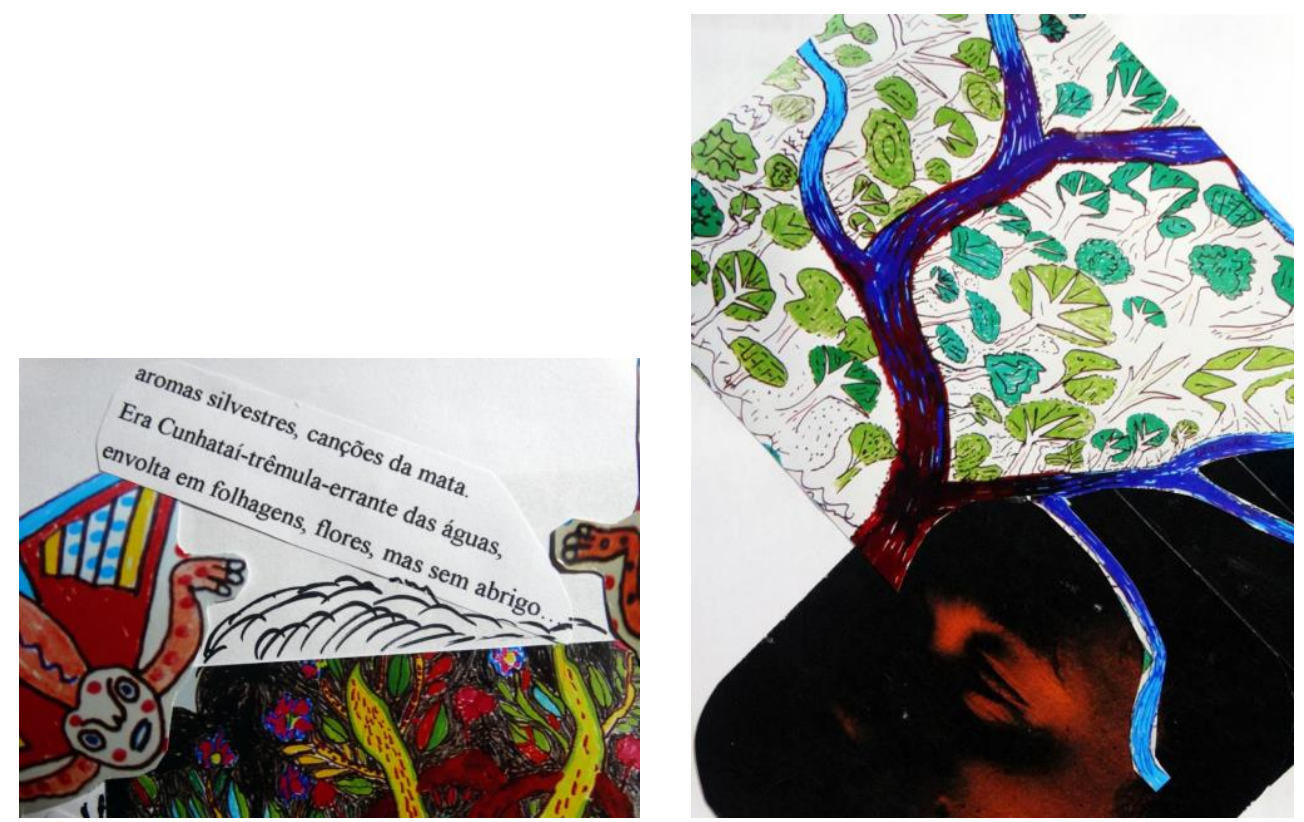

Imagem 11 e 12. Fonte: Oficina de criação com palavras e imagens.
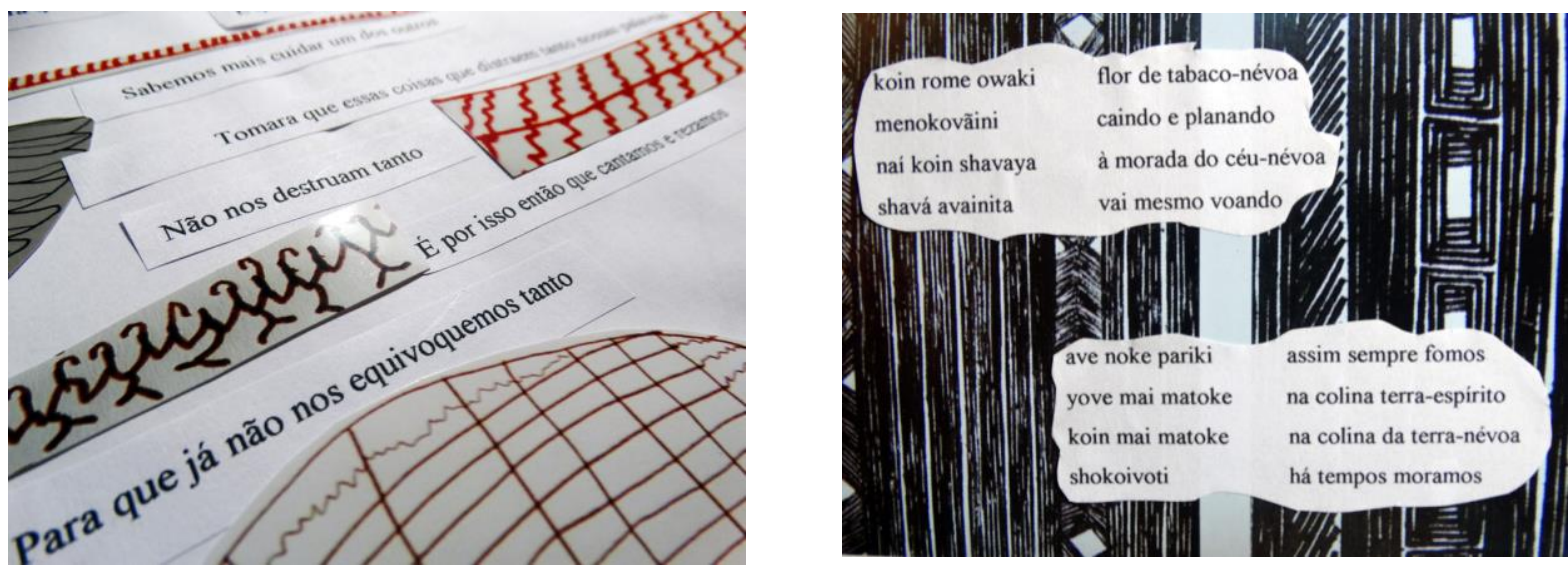

Imagem 13 e 14. Fonte: Oficina de criação com palavras e imagens.
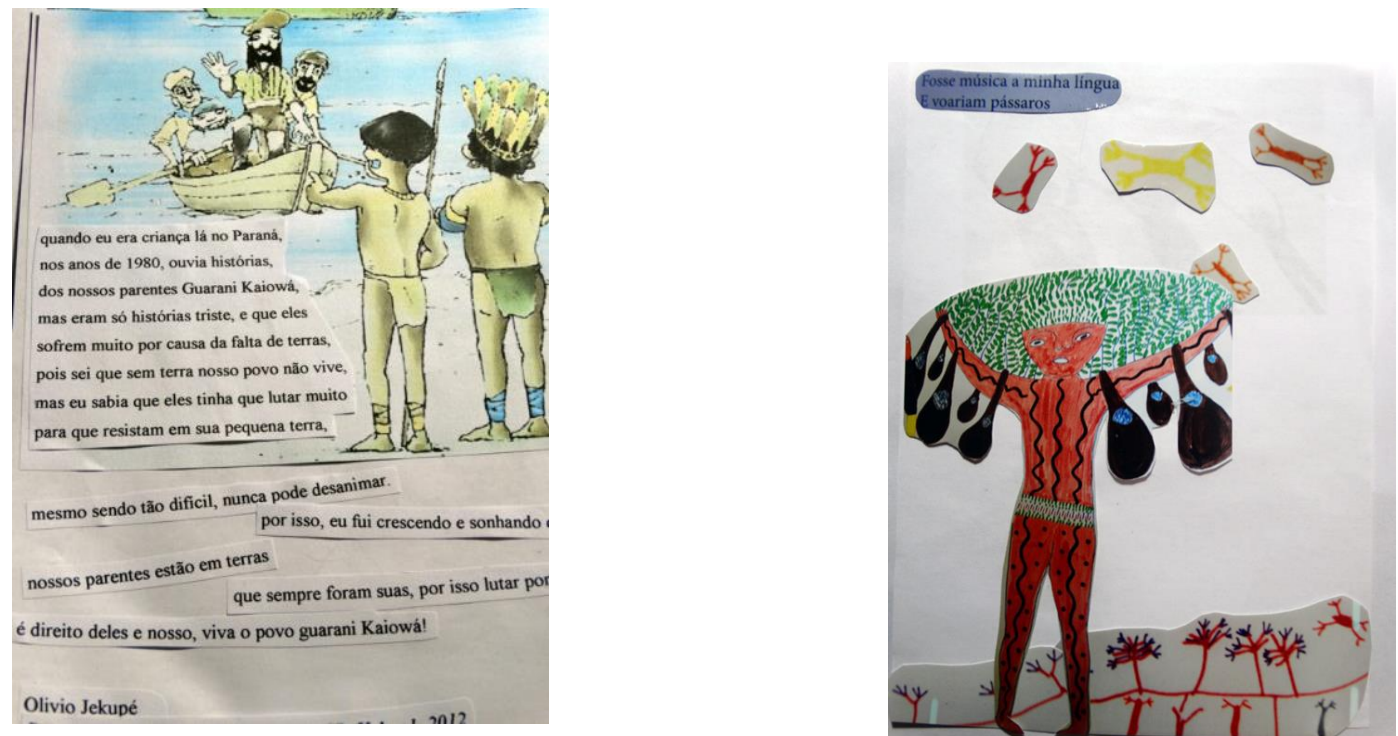

Imagem 15 e 16. Fonte: Oficina de criação com palavras e imagens.

Teias v. 18 •n. 51 • 2017 (Out./Dez.): Micropolítica, democracia e educação 
BIBLIOGRAFIA

ANDUJAR, C.; BARDI, P. M. Mitopoemas Yânomam. São Paulo: Olivetti do Brasil S.A, 1978.

BONIN, I. T. Povos indígenas na rede das temáticas escolares: o que isso nos ensina sobre identidades, diferenças e diversidade? Revista Currículo sem Fronteiras, v.10, n.1, p.73-83, Jan./Jun. 2010.

. Literatura infantil de autoria indígena: diálogos, mesclas, deslocamentos. Currículo sem Fronteiras, v. 12, n. 1, p. 36-52, Jan./Abr. 2012.

DELEUZE, G.; GUATARRI, F. Mil Platôs: capitalismo e esquizofrenia. Rio de Janeiro: Ed. 34, 1996. vol. 3.

GRUBER, J. G. (Org.). O Livro das Árvores Ticuna. Benjamin Constant: Organização Geral dos Professores Ticuna Bilingues, 1997.

JECUPÉ, C. W. Tupã Tenondé. A criação do Universo e da Terra e do Homem segundo a tradição oral Guarani. São Paulo: Peirópolis, 2001.

LATOUR, B. Petite Refléxion sur le Culte Moderne des Dieux Faîtiches. Le Plessis/Robinson: Institut Synthé-labo, 1996.

REVISTA LEETRA. Revista do Laboratório de Estudos da Linguagem da Universidade Federal de São Carlos, n.1, vol. 1, 2012.

Revista do Laboratório de Estudos da Linguagem da Universidade Federal de São Carlos. Antologia dos Morõngetas, n.2, vol. 2, 2013.

MUNDURUKU, D. Tempo, tempo, tempo. In: WUNDER, A.; NOVAES, M., MARQUES, D. Nas dobras do (im)possível: ensaios literários e imagéticos. Campinas: Leitura Crítica, 2017.

NHENETY KARIRI-XOCÓ. Não é lenda, é verdade. Blog Nhenety Kariri-Xocó - Cultura Digital, Cultura Popular, Blogs, História... Disponível em: 〈http://kxnhenety.blogspot.com.br/〉. Acesso em: 10 out. 2016.

ROLNIK, S. Ninguém é deleuziano. Entrevista. Núcleo de Estudos da Subjetividade. São Paulo, 1995. Disponível em: 〈http://www.pucsp.br/nucleodesubjetividade>. Acesso em: maio 2015.

VILELLA, E. Resistência e acontecimento. As palavras sem centro. In: GONDRA, J.; KOHAN W. (Orgs.). Foucault 80 anos, Belo Horizonte: Autêntica, 2016.

VIVEIROS DE CASTRO, E. Nativo Relativo. Mana, Rio de Janeiro, n. 8 (1), p. 113- 148, 2002.

Advertências In: SZTUMAN, R. (Org.). Encontros Eduardo Viveiro de Castro, Rio de Janeiro: Beco do Azougue, 2007.

Índio em Devir. In: FERNANDES, U. e HERRERO, M. (Orgs.). Baré, povo do rio. São Paulo: Edições SESC, 2015.

WUNDER, A. Encontros com poéticas indígenas, férteis fronteiras entre a educação e as artes. Revista de Educação Questio, Sorocaba, 20 (1), 2017. (no prelo).

; ROMAGUERA; A.; MARQUES, D. Ciranda de experimentações: giros que ressoam forças. Revista de Educação e Filosofia, Uberlândia, 32(62), 2017.

et. al. (In) visibilidades e poéticas indígenas. Revista ClimaCom Cultura Científica - pesquisa, jornalismo e arte. Campinas, ano 3, n.7, 2016. Disponível em: http://climacom.mudancasclimaticas.net.br/?p=6349. Acesso em: 10 set. 2016. 


\section{RESUMO}

O artigo envolve-se por três atravessamentos imagéticos que mobilizaram pensamentos sobre a criação de outras visibilidades aos povos indígenas nos currículos escolares. O encontro com um vídeo, com um livro e a realização de uma oficina de criação com palavras e imagens foram três movimentos que um curso sobre temática indígena na escola possibilitou. Como encontrar, como receber e se deixar atravessar por imagens de povos secularmente silenciados? Os indígenas nos oferecem outras palavras, outras imagens, mundos outros, ampliam possíveis e intensificam micropolíticas inventivas. As leituras de Gilles Deleuze e Félix Guattari sobre micropolíticas, de Eduardo Viveiros de Castro sobre o perspectivismo ameríndio e de outros autores nos convidam a deslocar as imagens construídas sobre os indígenas e a criar a partir de suas poéticas e regimes conceituais.

Palavras-chaves: imagens; povos indígenas; arte.

\section{(IN) VISIBILIDADES Y POÉTICAS INDÍGENAS EN LA ESCUELA: ATRAVESAMIENTOS IMAGÉTICOS RESUMEN}

El artículo se refiere a tres atravesamientos imagéticos que movilizaron pensamientos sobre la creación de otras visibilidades a los pueblos indígenas en los currículos escolares. El encuentro con un vídeo, con un libro y la realización de un taller de creación con palabras e imágenes fueron tres movimientos que un curso sobre temática indígena en la escuela posibilitó. ¿Cómo encontrar, cómo recibir y dejarse atravesar por imágenes de pueblos secularmente silenciados? Los indígenas nos ofrecen otras palabras, otras imágenes, mundos otros, amplían posibles e intensifican micropolíticas inventivas. Las lecturas del filósofo Gilles Deleuze e Félix Guattari sobre micropolítica, de Eduardo Viveiros de Castro sobre perspectivismo amerindio y de otros autores nos invitan a desplazar las imágenes construidas sobre los indígenas y crear a partir de sus poéticas y regímenes conceptuales.

Palabras-claves: imágenes; pueblos indígenas; arte.

\section{(IN)VISIBILITIES AND INDIGENOUS POETICS IN SCHOOL: ENCOUNTERS WITH IMAGES ABSTRACT}

The article deals with three encounters with images that stimulated thoughts about the possibility of creating other ways of expanding the visibility of indigenous peoples in school curriculum. An encounter with a video, a book and the presentation of a creative workshop using words and images were three exercises that a school course on indigenous matters made possible. How to find, receive and allow oneself to be moved by images of historically silenced peoples? The natives offer us other words, images and worlds, expand possibilities and intensify inventive micropolitics. Gilles Deleuze and Félix Guattari's concept of micropolitics, Eduardo Viveiros de Castro's concept of Amerindian perspectivism and other authors invite us to deconstruct images made about natives and to create from their poetics and their conceptual frameworks.

Keywords: images; indigenous peoples; art. 